\title{
Analisis Pengetahuan Dan Perilaku Masyarakat Di Kelurahan Baru Kotawaringin Barat Tentang Covid 19
}

\section{Dyah Restuning Prihati ${ }^{1}$, Maulidta K.Wirawati ${ }^{2}$, Endang Supriyanti ${ }^{3}$}

\author{
${ }^{1}$ Dosen AKPER Widya Husada Semarang \\ Email : Dyah.erpe@gmail.com \\ ${ }^{2}$ Dosen AKPER Widya Husada Semarang \\ Email :maulidtakw@gmail.com \\ ${ }^{3}$ Dosen AKPER Widya Husada Semarang \\ Email :lithafikha@gmail.com
}

\section{ABSTRACT: ANALYSIS OF COMMUNITY KNOWLEDGE AND BEHAVIOR IN KELURAHAN BARU, WEST KOTAWARINGIN ABOUT COVID 19}

Background :Coronavirus Disease 2019 (COVID-19) is a new type of disease that has never been previously identified in humans. COVID-19 becomes a global health problem in early 2020 ,. The importance of awareness from the public to break the chain of transmission of COVID-19. Knowledge and attitudes from the community become benchmarks for public awareness. Promotional and preventive efforts need to be carried out by health workers, especially the community. The Indonesian government has declared a disaster emergency status related to this virus pandemic. The government made a policy to implement physical distancing to decide the spread of covid 19.

Purpose: to analyze the knowledge and behavior of the people in Kelurahan Baru, Kotawaringin Barat about COVID - 19

Methods: This study used a quantitative descriptive research design with a survey approach in Kelurahan Baru, Kotawaringin Barat. The population in the study was 50 people. The research period was May-June 2020. In this study, researchers collected data using an instrument in the form of a questionnaire covering respondent characteristics, knowledge and behavior.

Results: The results of this study indicate that $100 \%$ of respondents $(50$ people) have a good level of knowledge and as many as 23 (46\%) of respondents have good enough behavior in preventing COVID-19. Respondent's age, gender and occupation did not have a relationship with behavior in preventing COVID19. There is a relationship between the education level of respondents and behavior in preventing COVID-19 $(p=0.04)$.

Conclusion: respondents have a good level of knowledge and behavior in preventing COVID-19. There needs to be awareness from the public to comply with health protocols during the COVID-19 pandemic. In addition, the role of health workers in socialization and monitoring in the community is important in preventing COVID-19.

Keywords: Knowledge, Community Behavior, COVID 19

Dyah Restuning Prihati ${ }^{1}$, Maulidta K. $W^{2}$, Endang Supriyanti ${ }^{3}$

${ }^{1}$ Dosen AKPER Widya Husada Semarang. Email : Dyah.erpe@gmail.com

${ }^{2}$ Dosen AKPER Widya Husada Semarang. Email :maulidtakw@gmail.com

${ }^{3}$ Dosen AKPER Widya Husada Semarang. Email :lithafikha@gmail.com 


\section{INTISARI: ANALISIS PENGETAHUAN DAN PERILAKU MASYARAKAT DI KELURAHAN BARU, KOTAWARINGIN BARAT TENTANG COVID 19}

\section{Latar Belakang :}

Coronavirus Disease 2019 (COVID-19) adalah penyakit jenis baru yang belum pernah diidentifikasi sebelumnya pada manusia. COVID-19 menjadi masalah kesehatan Dunia pada awal tahun 2020,. Pentingnya kesadaran dari masyarakat untuk memutus rantai penularan COVID-19. Pengetahuan dan sikap dari masyarakat menjadi tolak ukur tentang kesadaran masyarakat. Upaya promotif dan preventif perlu dilakukan oleh petugas kesehatan, khususnya masyarakat. Pemerintah Indonesia telah menetapkan status darurat bencana yang terkait dengan pandemi virus ini. Pemerintah membuat kebijakan untuk menerapkan physical distancing untuk memutuskan penyebaran covid 19.

Tujuan : untuk menganalisa pengetahuan dan perilaku masyarakat di Kelurahan Baru, Kotawaringin Barat Tentang COVID -19

Metode Penelitian: Penelitian ini menggunakan desain penelitian deskriptif kuantitatif dengan pendekatan survey di Kelurahan Baru, Kotawaringin Barat. Populasi pada penelitian sebanyak 50 orang. Waktu penelitian bulan Mei- Juni 2020. Pada penelitian ini, peneliti mengumpulkan data dengan menggunakan instrumen berupa kuesioner meliputi karakteristik responden, pengetahuan dan perilaku.

Hasil: Hasil penelitian ini menunjukkan bahwa $100 \%$ responden ( 50 orang) memiliki tingkat pengetahuan baik dan sebanyak 23 (46\%) responden mempunyai perilaku cukup baik dalam pencegahan COVID-19. Usia responden, Jenis kelamin dan jenis pekerjaan responden tidak memiliki hubungan dengan perilaku dalam pencegahan COVID-19. Terdapat hubungan tingkat pendidikan responden dengan perilaku dalam pencegahan COVID-19 $(p=0.04)$.

Kesimpulan: responden memiliki tingkat pengetahuan baik dan perilaku cukup dalam pencegahan COVID-19. Perlu ada kesadaran dari masyarakat untuk mentaati protokol kesehatan dimasa pandemi COVID-19. Selain itu pentingnya peran petugas kesehatan sosialisasi dan pemantauan di masyarakat dalam pencegahan COVID-19.

Kata Kunci: Pengetahuan, Perilaku Masyarakat, COVID 19

\section{PENDAHULUAN}

Coronavirus Disease 2019 (COVID-19) adalah penyakit jenis baru yang menyerang saluran pernafasan. COVID-19 menjadi masalah kesehatan Dunia pada awal tahun 2020,. Kasus ini diawali dengan informasi dari Badan Kesehatan Dunia/World Health Organization (WHO) pada tanggal 31 Desember 2019 adanya kasus kluster

pneumonia dengan etiologi yang tidak jelas di Kota Wuhan, Provinsi Hubei, China. Kasus ini meningkat dengan adanya laporan kematian dan terjadi importasi di luar China (Chen et al., 2020). Pada tanggal 30 Januari 2020, WHO menetapkan COVID-19 sebagai Public Health Emergency of International Concern (PHEIC)/ Kedaruratan Kesehatan

Dyah Restuning Prihati ${ }^{1}$, Maulidta K. W $^{2}$, Endang Supriyanti ${ }^{3}$

${ }^{1}$ Dosen AKPER Widya Husada Semarang. Email : Dyah.erpe@gmail.com

${ }^{2}$ Dosen AKPER Widya Husada Semarang. Email :maulidtakw@gmail.com

${ }^{3}$ Dosen AKPER Widya Husada Semarang. Email :lithafikha@gmail.com 
Masyarakat Yang Meresahkan Dunia (KKMMD). Pada tanggal 12 Februari 2020, WHO resmi menetapkan penyakit novel coronavirus pada manusia ini dengan sebutan Coronavirus Disease (COVID-19).

Pada tanggal 2 Maret 2020 Indonesia telah melaporkan 2 kasus konfirmasi COVID-19. Pada tanggal 11 Maret 2020, WHO sudah menetapkan COVID-19 sebagai pandemi (World Health Organization, 2020).

Menurut juru bicara Gugus Tugas Percepatan Penanganan COVID-19 Data yang ditemukan di Kotawaringin Barat pada bulan Mei 2020 dari 29 orang positif COVID-19, sebanyak 27 orang masih dalam masyarakatan dan 2 orang dinyatakan sembuh. Masyarakat mendapatkan sumber informasi dari media sosial, media massa tentang COVID-19. Berdasarkan wawancara dengan 10 orang warga, mereka dapat menjelaskan tanda gejala dan pencegahan COVID-19. Hasil observasi di kelurahan baru ditemukan $50 \%$ warga tidak menggunakan masker saat beraktifitas di luar rumah, terlihat

\section{METODE}

Penelitian ini menggunakan desain penelitian deskriptif kuantitatif dengan pendekatan survey yaitu menyajikan potret keadaan yang bisa mengajukan hipotesis dan tidak mencari sebab suatu masalah. Pada penelitian ini mendapatkan gambaran tentang Pengetahuan dan Perilaku Masyarakat Tentang COVID- 19. Lokasi penelitian di Kelurahan Baru, Kotawaringin Barat. Waktu penelitian bulan Mei- Juni 2020. kerumunan orang di pasar tanpa menjaga jarak dan 25\% warga kelurahan baru dengan usia lansia. Dengan data tersebut pentingnya pemerintah untuk mengantisipasi kejadian penambahan kasus positif COVID-19. Pentingnya kesadaran dari masyarakat untuk memutus rantai penularan COVID-19.

Pengetahuan dan sikap dari masyarakat menjadi tolak ukur tentang kesadaran masyarakat. Upaya promotif dan preventif perlu dilakukan oleh petugas kesehatan, khususnya masyarakat. Pemerintah Indonesia telah menetapkan status darurat bencana yang terkait dengan pandemi virus ini (Tim Kerja Kementerian Dalam Negeri, 2020). Pemerintah membuat kebijakan untuk menerapkan physical distancing untuk memutuskan penyebaran COVID-19. Berdasarakan fenomena yang ditemukan di Kelurahan Baru, penulis tertarik untuk melakukan penelitian tentang analisis pengetahuan dan perilaku masyarakat di kelurahan baru, kotawaringin barat tentang COVID19.

Instrumen yang digunakan berupa kuesioner terdiri karakteristik responden meliputi usia, jenis kelamin, tingkat pendidikan, dan pekerjaan. Sedangkan kuesioner pengetahuan tentang COVID-19 berisi 10 pernyataan yang disertai dengan alternatif jawaban benar atau salah. Setiap pernyataan mendapat nilai 1 untuk jawaban yang benar dan nilai 0 untuk jawaban yang salah. Penilaian dilakukan dengan cara

Dyah Restuning Prihati ${ }^{1}$, Maulidta K. $W^{2}$, Endang Supriyanti ${ }^{3}$

${ }^{1}$ Dosen AKPER Widya Husada Semarang. Email : Dyah.erpe@gmail.com

${ }^{2}$ Dosen AKPER Widya Husada Semarang. Email :maulidtakw@gmail.com

${ }^{3}$ Dosen AKPER Widya Husada Semarang. Email :lithafikha@gmail.com 
membandingkan jumlah skor jawaban dengan skor yang diharapkan (tertinggi) kemudian dikalikan $100 \%$ yang hasilnya berupa persentase (Sudijono, 2006). Kuesioner perilaku terdiri dari 15 pertanyaan, untuk mengkategorikan hasil pengukuran perilaku yaitu : Rendah $X<M$-SD, Sedang $M$ $1 S D<X<M+1 S D$, Tinggi $M+1 S D<X$ (Azwar,2012). Uji validitas serta reliabilitas dilakukan hasil yang diperoleh valid untuk setiap item pertanyaan $(r>0,45)$ dengan nilai Cronbach's alpha sebesar 0,764. Sebanyak 50 responden dilibatkan dalam penelitian ini dan mengisi kuesioner dengan sebelumnya memberikan pernyataan kesediaan terlebih dahulu

dan menandatangani informed consent. Penelitian ini menggunakan analisis data univariat yang terdiri dari usia, jenis kelamin, pendidikan, pekerjaan dan tingkat pengetahuan serta perilaku tentang pencegahan COVID-19. Data ini dianalisis dengan menggunakan tabel distribusi frekuensi. Analisis bivariat untuk melakukan analisis hubungan variable katagorik dengan variabel katagorik dilakukan dengan menggunakan uji statistik chi square) dengan aplikasi SPPS 16.0 nilai kemaknaan $p<0,05$. Penelitian ini telah mendapatkan persetujuan dari Komisi Etik Penelitian AKPER Widya Husada Semarang dengan nomor 05 /KEP/1V/2020.

HASIL

Analisis Univariat

Distribusi Frekuensi Karakteristik Responden di Kelurahan Baru, Kotawaringin Barat

\begin{tabular}{lcc}
\hline \multicolumn{1}{c}{ Karakteristik } & $\mathrm{n}$ & $\%$ \\
\hline Usia & & \\
$20-30$ th & 19 & 38 \\
$30-45$ th & 17 & 34 \\
45 th & 14 & 28 \\
Jenis Kelamin & & \\
$\quad$ Laki - laki & 23 & 46 \\
Perempuan & 27 & 54 \\
Pendidikan & & \\
SD & 9 & 18 \\
SMP & 8 & 16 \\
SMA & 29 & 58 \\
D3 / S1 & 4 & 8 \\
Pekerjaan & & \\
Karyawan swasta & 28 & 56 \\
Wiraswasta & 5 & 10 \\
Tidak bekerja & 17 & 34 \\
\hline
\end{tabular}

Berdasarkan tabel, diketahui dari 50 responden sebanyak 19 (38\%) responden usia 20-30 tahun, responden berusia 30-35 tahun

Dyah Restuning Prihati ${ }^{1}$, Maulidta K. W $^{2}$, Endang Supriyanti ${ }^{3}$

${ }^{1}$ Dosen AKPER Widya Husada Semarang. Email : Dyah.erpe@gmail.com

${ }^{2}$ Dosen AKPER Widya Husada Semarang. Email :maulidtakw@gmail.com

${ }^{3}$ Dosen AKPER Widya Husada Semarang. Email :lithafikha@gmail.com 
sebanyak 17 (34\%) dan responden usia lebih dari 45 tahun sebanyak 14 (28\%), sehingga dapat disimpulkan sebagian besar responden berusia 20-30 tahun. Berdasarkan tabel, diketahui dari 50 responden sebanyak $23(46 \%)$ berjenis kelamin laki-laki, dan sebanyak 27 (54\%) responden berjenis kelamin perempuan, sehingga dapat disimpulkan sebagian besar responden berjenis kelamin perempuan. Berdasarkan tabel, diketahui dari 50 responden sebanyak 9 (18\%) responden dengan pendidikan SD, responden dengan pendidikan SMP sebanyak $8(16 \%)$, responden dengan pendidikan SMA sebanyak 29 (58\%) dan responden dengan pendidikan D3 atau S1 sebanyak 4 (8\%), sehingga dapat disimpulkan sebagian besar responden dengan pendidikan SMA. Berdasarkan tabel, diketahui dari 50 responden sebanyak 28 (56\%) bekerja sebagai karyawan swasta, responden bekerja sebagai wiraswasta sebanyak 5 (10\%) dan sebanyak 17 (34,\%) responden tidak bekerja, sehingga dapat disimpulkan sebagian besar responden bekerja sebagai karyawan swasta.

Tingkat pengetahuan responden tentang COVID-19.

Distribusi Frekuensi Tingkat Pengetahuan di Kelurahan Baru, Kotawaringin Barat

\begin{tabular}{lcc}
\hline Variabel & Frekuensi & Presentase \\
\hline Baik & 50 & 100 \\
\hline Total & 50 & 100 \\
\hline
\end{tabular}

Berdasarkan tabel, diketahui dari 50 responden (100\%) memiliki tingkat pengetahuan baik.

\section{Perilaku responden dalam Pencegahan COVID-19}

Distribusi Frekuensi Berdasarkan Tingkat Perilaku dalam Pencegahan COVID19 di Kelurahan Baru, Kotawaringin Barat

\begin{tabular}{lcc}
\hline Variabel & Frekuensi & Presentase \\
\hline Baik & 9 & 18 \\
\hline Cukup & 23 & 46 \\
\hline Kurang & 18 & 36 \\
\hline Total & 50 & 100 \\
\hline
\end{tabular}

Berdasarkan tabel, diketahui dari 50 responden sebanyak $9(18 \%)$ responden dengan perilaku baik, responden dengan perilaku cukup baik sebanyak 23 (46\%) dan responden dengan perilaku kurang baik sebanyak 18 (36\%), sehingga dapat disimpulkan sebagian besar responden berperilaku cukup baik.

Dyah Restuning Prihati ${ }^{1}$, Maulidta K. $W^{2}$, Endang Supriyanti ${ }^{3}$

${ }^{1}$ Dosen AKPER Widya Husada Semarang. Email : Dyah.erpe@gmail.com

${ }^{2}$ Dosen AKPER Widya Husada Semarang. Email :maulidtakw@gmail.com

${ }^{3}$ Dosen AKPER Widya Husada Semarang. Email :lithafikha@gmail.com 


\section{Analisis Bivariat}

Analisis hubungan antara Karakteristik Responden dengan Perilaku dalam Pencegahan COVID-19 di Kelurahan Baru, Kotawaringin Barat

\begin{tabular}{|c|c|c|c|c|c|c|c|}
\hline \multirow[t]{3}{*}{ Variabel } & \multicolumn{6}{|c|}{ Tingkat Perilaku } & \multirow{3}{*}{$p$} \\
\hline & \multicolumn{2}{|c|}{$\begin{array}{c}\text { Baik } n=9 \\
(18 \%)\end{array}$} & \multicolumn{2}{|c|}{$\begin{array}{c}\text { Cukup } n=23 \\
(46 \%)\end{array}$} & \multicolumn{2}{|c|}{$\begin{array}{c}\text { Kurang } n=18 \\
(23 \%)\end{array}$} & \\
\hline & $\mathrm{n}$ & $\%$ & $\mathrm{n}$ & $\%$ & $\mathrm{n}$ & $\%$ & \\
\hline \multicolumn{8}{|l|}{ Usia } \\
\hline $20-30$ th & 1 & $2.0 \%$ & 8 & $16 \%$ & 10 & $20 \%$ & \\
\hline $30-45$ th & 4 & $8.0 \%$ & 10 & $20 \%$ & 3 & $6.0 \%$ & 0.14 \\
\hline$>45$ th & 4 & $8.0 \%$ & 5 & $10 \%$ & 5 & $10 \%$ & \\
\hline \multicolumn{8}{|l|}{ Jenis Kelamin } \\
\hline Laki - laki & 6 & $12 \%$ & 11 & $22 \%$ & 6 & $12 \%$ & \\
\hline Perempuan & 3 & $6 \%$ & 12 & $24 \%$ & 12 & $24 \%$ & 0.25 \\
\hline \multicolumn{8}{|l|}{ Pendidikan } \\
\hline SD & 2 & $4 \%$ & 7 & $14 \%$ & 0 & $0 \%$ & \\
\hline SMP & 0 & $0 \%$ & 7 & $14 \%$ & 1 & $2 \%$ & \\
\hline SMA & 7 & $14 \%$ & 6 & $12 \%$ & 16 & $32 \%$ & 0.04 \\
\hline D3 / S1 & 0 & $0 \%$ & 3 & $6 \%$ & 1 & $2 \%$ & \\
\hline \multicolumn{8}{|l|}{ Pekerjaan } \\
\hline Karyawan swasta & 6 & $12 \%$ & 12 & $24 \%$ & 10 & $20 \%$ & \\
\hline Wiraswasta & 1 & $2 \%$ & 1 & $2 \%$ & 3 & $6.0 \%$ & 0.56 \\
\hline Tidak bekerja & 2 & $4 \%$ & 10 & $20 \%$ & 5 & $10 \%$ & \\
\hline
\end{tabular}

Berdasarkan tabel memperlihatkan bahwa hasil uji statistik diperoleh $p$-value $=0.14$ yang berarti >a, maka dapat disimpulkan bahwa usia responden tidak memiliki hubungan yang signifikan terhadap perilaku dalam pencegahan COVID-19. Berdasarkan tabel memperlihatkan bahwa hasil uji statistik diperoleh $p$-value $=0.25$ yang berarti >a, maka dapat disimpulkan bahwa jenis kelamin responden tidak memiliki hubungan yang signifikan terhadap perilaku dalam pencegahan COVID-19).
Berdasarkan tabel memperlihatkan bahwa hasil uji statistik diperoleh $p$-value $=0.04$ yang berarti $<a$, maka dapat disimpulkan bahwa tingkat pendidikan responden memiliki hubungan yang signifikan terhadap perilaku dalam pencegahan COVID-19. Berdasarkan tabel memperlihatkan bahwa hasil uji statistik diperoleh $p$-value $=0.56$ yang berarti $>a$, maka dapat disimpulkan bahwa jenis pekerjaan responden tidak memiliki hubungan yang signifikan terhadap perilaku dalam pencegahan COVID-19.

Dyah Restuning Prihati ${ }^{1}$, Maulidta K. $W^{2}$, Endang Supriyanti ${ }^{3}$

${ }^{1}$ Dosen AKPER Widya Husada Semarang. Email : Dyah.erpe@gmail.com

${ }^{2}$ Dosen AKPER Widya Husada Semarang. Email :maulidtakw@gmail.com

${ }^{3}$ Dosen AKPER Widya Husada Semarang. Email :lithafikha@gmail.com 


\section{PEMBAHASAN}

Pengetahuan yaitu sesuatu yang ditangkap melalui pancaindera yakni penglihatan, pendengaran, penciuman, perabaan dan perasaan terhadap suatu obyek sehingga mampu dimengerti dan dipahami seseorang. Hasil penelitian menunjukkan sebanyak 19 (38\%) responden usia 20-30 tahun merupakan usia dewasa. Umur mempengaruhi terhadap daya tangkap dan pola pikir seseorang. Dengan bertambahnya umur individu, daya tangkap dan pola pikir seseorang akan lebih berkembang, sehingga pengetahuan yang diperolehnya semakin membaik (Notoatmodjo, 2007). Pada usia 20-30 tahun adalah usia yang matang dimana seseorang pada usia tersebut akan mempunyai pertimbangan dalam menangkap informasi dan mempunyai daya pikir yang baik. Hasil penelitian ini tidak sesuai dengan penelitian yang dilakukan oleh Wulandari (2020) yang menjelaskan bahwa tidak ada hubungan yang signifikan antara umur dengan pengetahuan masyarakat di Kalimantan Selatan mengenai pencegahan Covid-19. Hal ini dijelaskan bahwa terdapat faktor fisik yang mempengaruhi dan menghambat proses belajar diantaranya gangguan penglihatan atau pendengaran sehingga membuat penurunan dalam berpikir. Faktor lain yang juga menghambat proses berpikir adalah kondisi fisiologis dan psikologi seseorang seperti kondisi seseorang ketika sakit atau ada keterbatasan dalam indra.

Pengetahuan juga dipengaruhi oleh pendidikan. Dari hasil penelitian diketahui bahwa tingkat pendidikan diperoleh bahwa terbanyak adalah 29 orang (58\%) lulusan SMA dan 4 orang (8\%) responden lulusan S1. Hal ini sejalan dengan yang dikatakan Notoatmodjo (2007) Semakin tinggi seseorang menempuh pendidikan, semakin mudah sesorang mendapatkan informasi. Seseorang dengan pendidikan tinggi, maka semakin luas pengetahuannya dalam menerima informasi dalam hal ini tentang COVID-19.

Pada penelitian ini menunjukkan bahwa sebanyak 28 (56\%) responden bekeja sebagai karyawan swasta. Menurut Mubarak (2011) Lingkungan pekerjaan dapat membuat seseorang memperoleh pengalaman dan pengetahuan baik secara langsung maupun tidak langsung. Lingkungan berpengaruh terhadap proses masuknya pengetahuan ke dalam individu. Faktor-faktor yang mempengaruhi pengetahuan adalah pendidikan, keterpaparan informasi, pengalaman dan lingkungan (Meliono, n.d.). Hasil penelitian ini sejalan dengan penelitian yang dilakukan oleh Yanti B, dkk (2020) yang menyebutkan bahwa ada hubungan yang erat pengetahuan dengan tingkat pendidikan. Tingkat pendidikan seseorang yang tinggi akan semkin mudah untuk mendapatkan akses informasi tentang suatu permasalahan (Yanti et al., 2020). Tetapi berbeda dengan penelitian yang dilakukan Wulandari 2020 menunjukkan bahwa tidak ada hubungan yang signifikan antara pendidikan, dan pekerjaan dengan pengetahuan masyarakat di Kalimantan Selatan mengenai pencegahan Covid-19,

Dyah Restuning Prihati ${ }^{1}$, Maulidta K. W $^{2}$, Endang Supriyanti ${ }^{3}$

${ }^{1}$ Dosen AKPER Widya Husada Semarang. Email : Dyah.erpe@gmail.com

${ }^{2}$ Dosen AKPER Widya Husada Semarang. Email :maulidtakw@gmail.com

${ }^{3}$ Dosen AKPER Widya Husada Semarang. Email :lithafikha@gmail.com 
sehingga berbeda dengan hasil penelitian ini. Tidak adanya hubungan antara pekerjaan dengan pengetahuan masyarakat di Kalimantan Selatan tentang pencegahan Covid-19 disebabkan karena antara responden yang bekerja dan tidak bekerja dengan pengetahuan rendah tentang pencegahan Covid-19. bahwa pengetahuan yang didapatkan oleh masyarakat dengan pendidikan rendah mengenai penularan Covid19 tidak hanya dari pendidikan formal tetapi dari pengalaman dirinya maupun lingkungan kehidupan bermasyarakat (Wulandari et al., 2020). Karena penyakit covid ini baru ditemukan tahun 2019 sehingga masyarakat belum banyak mempunyai informasi tentang penyakit covid 19 .

Hasil penelitian ini menunjukkan bahwa $100 \%$ responden ( 50 orang) memiliki tingkat pengetahuan baik. Hasil penelitian ini juga menunjukkan responden dengan perilaku cukup baik dalam pencegahan COVID-19 sebanyak 23 (46\%) responden. Penelitian ini menunjukkan bahwa semakin baik pengetahuan masyarakat, maka semakin baik pula tindakan masyarakat dalam pencegahan COVID-19. Namun dalam penelitian ini juga terdapat responden dengan perilaku kurang sebanyak 18 orang (36\%). Menerapkan perilaku sehat dalam pencegahan COVID-19, merupakan langkah ampuh untuk menangkal penyakit, namun dalam praktiknya, penerapan ini yang kesannya sederhana tidak selalu mudah dilakukan terutama bagi responden yang tidak terbiasa, kurangnya pengetahuan dan sedikitnya kesadaran berperilaku hidup sehat. Upaya yang dapat dilakukan untuk menghadapi COVID 19 adalah melakukan physical distancing, rajin mencuci tangan dengan sabun, menggunakan masker bila keluar rumah, serta menjalankan (Kemenkes, 2020). Penelitian yang dilakukan oleh Natalia (2020) menunjukkan bahwa terdapat hubungan yang signifikan antara pengetahuan dan kesiapsiagaan $(\mathrm{p}=.006)$ dengan arah positif $(r=269)$, bahwa semakin tinggi pengetahuan, semakin tinggi kesiapsiagaan.

Hasil penelitian ini menunjukkan usia responden tidak memiliki hubungan yang signifikan terhadap perilaku dalam pencegahan COVID-19 $(p=1.4)$, Jenis kelamin responden tidak memiliki hubungan yang signifikan terhadap perilaku dalam pencegahan COVID$19 \quad(p=0.25)$, jenis pekerjaan responden tidak memiliki hubungan yang signifikan terhadap perilaku dalam pencegahan COVID-19 $(p=0.56)$ dan tingkat pendidikan responden memiliki hubungan yang signifikan terhadap perilaku dalam pencegahan COVID-19 ( $\mathrm{p}=0.04)$ (Natalia, Malinti, \& Elon, 2020). Penelitian ini menunjukkan bahwa semakin baik pengetahuan masyarakat, maka semakin baik pula tindakan masyarakat dalam pencegahan Covid-19. Perilaku dalam bentuk tindakan dapat diobservasi secara langsung melalui wawancara dan kegiatan responden dalam bentuk tindakan nyata/ tindakan seseorang dalam pencegahan COVID-19 Penelitian ini sejalan dengan penelitian yang dilakukan oleh Purnamasari 2020

Dyah Restuning Prihati ${ }^{1}$, Maulidta K. W $^{2}$, Endang Supriyanti ${ }^{3}$

${ }^{1}$ Dosen AKPER Widya Husada Semarang. Email : Dyah.erpe@gmail.com

${ }^{2}$ Dosen AKPER Widya Husada Semarang. Email :maulidtakw@gmail.com

${ }^{3}$ Dosen AKPER Widya Husada Semarang. Email :lithafikha@gmail.com 
yang melakukan penelitian pada masyarakat wonosobo. Hasil dari peneltian tersebut adalah masyarakat wonosobo mempunyai perilakuk yang baik pada pencegahan covid 19.

Perilaku yang baik merupakan upaya untuk mencegah penularan covi 19 (Purnamasari, 2020). Kepatuhan dalam melakukan pencegahan covid dipengaruhi oleh beberapa faktor antaralain pengetahuan, persepsi, motivasi dan keyakinan terhadap upaya pengontrolan dan pencegahan penyakit, terhadap lingkungan, pelayanan kesehatan, dan kemampuan mengakses sumber yang ada (Sinuraya, 2018). Menurut teori Model Pengetahuan- SikapPerilaku, pengetahuan merupakan faktor esensial yang dapat mempengaruhi perubahan perilaku,

\section{KESIMPULAN}

1. Hasil penelitian ini menunjukkan tingkat pengetahuan responden baik serta menunjukkan perilaku cukup baik dalam pencegahan COVID-19.

2. Usia responden, Jenis kelamin dan jenis pekerjaan responden tidak memiliki hubungan dengan perilaku pencegahan COVID-19.

3. Terdapat hubungan tingkat pendidikan responden dengan perilaku pencegahan COVID-19. dan individu dapat memperoleh pengetahuan dan ketrampilan melalui proses belajar (Liu, Liu, Wang, An, \& Jiao, 2016). Sedangkan, ketidakpatuhan adalah kondisi ketika seseorang berkeinginan untuk patuh, tetapi ada beberapa faktor yang menghambat kepatuhan seseorang terhadap upaya promotif maupun preventif kesehatan (Prihantana, 2016).

Masyarakat tidak patuh terhadap protokol kesehatan pandemi COVID-19 disebabkan masyarakat kurang memiliki pemahaman resiko tertular COVID19, tujuan pencegahan, dan bagaimana prosedur pemakaian APD. Jika masyarakat memiliki persepsi yang baik, maka resiko tertular COVID-19 bisa dicegah.

Perlu ada kesadaran dari masyarakat untuk mentaati protokol kesehatan dimasa pandemi COVID19 dengan perubahan perilaku yaitu menggunakan masker, physical distancing serta perilaku hidup sehat dan bersih. Selain itu pentingnya peran petugas kesehatan sosialisasi dan pemantauan di masyarakat dalam pencegahan COVID-19.

\section{DAFTAR PUSTAKA}

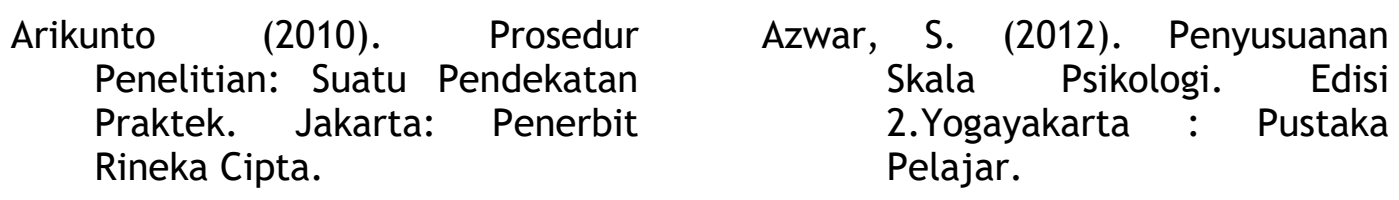

Dyah Restuning Prihati ${ }^{1}$, Maulidta K. $W^{2}$, Endang Supriyanti ${ }^{3}$

${ }^{1}$ Dosen AKPER Widya Husada Semarang. Email : Dyah.erpe@gmail.com

${ }^{2}$ Dosen AKPER Widya Husada Semarang. Email :maulidtakw@gmail.com

${ }^{3}$ Dosen AKPER Widya Husada Semarang. Email :lithafikha@gmail.com 
Chan JF, To KK, Tse H, Jin DY, Yuen $\mathrm{KY}$. Interspecies transmission and emergence of novel viruses: lessons from bats and birds. Trends Microbiol. 2013 Oct;21(10):544-55.

https: / / www.sciencedirect.co $\mathrm{m} / \mathrm{science} / \mathrm{article} / \mathrm{abs} / \mathrm{pii} / \mathrm{S} 09$ $66842 X 13000899$.

Chen, N., Zhou, M., Dong, X., Qu, J., Gong, F., Han, Y., ... Zhang, L. (2020). Epidemiological and clinical characteristics of 99 cases of 2019 novel coronavirus pneumonia in Wuhan, China: a descriptive study. The Lancet, 395(10223), 507-513. https://doi.org/10.1016/S0140 $-6736(20) 30211-7$

Fitriani, S. (2011). Promosi Kesehatan, Yogyakarta : Graha Ilmu

\section{Kementerian Kesehatan RI Direktorat Jenderal Pencegahan dan Pengendalian Penyakit (P2P) (2020). Pedoman Pencegahan dan Pengendalian Coronavirus Disease (COVID-19) Revisi ke-4. Jakarta. \\ http: / /infeksiemerging. kemkes .go.id}

Kemenkes. (2020). Pedoman kesiapan menghadapi COVID19. In Direktorat Jenderal Pencegahan dan pengendalian penyakit. Kemetrian Kesehatan RI.

https://www.kemkes.go.id/res ources/download/infoterkini/ COVID-19 dokumen resmi/2 Pedoman Pencegahan dan Pengendalian Coronavirus
Disease (COVID-19).pdf

Kemenkes. (2020). Pedoman kesiapan menghadapi COVID19. Pedoman Kesiapan Menghadapi COVID-19, 0-115.

Liu, L., Liu, Y. P., Wang, J., An, L. W., \& Jiao, J. M. (2016). Use of a knowledge-attitudebehaviour education programme for Chinese adults undergoing maintenance haemodialysis: Randomized controlled trial. Journal of International Medical Research, 44(3), 557-568. https: / /doi.org/10.1177/03000 60515604980

Meliono, I. (2011). (n.d.). Pengetahuan. In Pengetahuan. Retrieved from https: //id.wikipedia.org/w/ind ex.php?title=Pengetahuan\&oldi $d=17137528$

Mubarak, W. (2011). Promosi Kesehatan untuk Kebidanan. Jakarta: Salemba Medika.

Natalia, R. N., Malinti, E., \& Elon, Y. (2020). Kesiapsiagaan Remaja Dalam Menghadapi Wabah Covid-19. Jurnal Ilmiah Kesehatan Diagnosis, 15(2), 107-111.

Notoatmojo. (2007). Promosi Kesehatan dan Ilmu Perilaku. Jakarta: Rineka Cipta.

Notoatmojo. (2010). Pendidikan dan Perilaku Kesehatan. Jakarta: Rineka Cipta.

Prihantana. (2016). Hubungan Pengetahuan dengan Tingkat

Dyah Restuning Prihati ${ }^{1}$, Maulidta K. $W^{2}$, Endang Supriyanti ${ }^{3}$

${ }^{1}$ Dosen AKPER Widya Husada Semarang. Email : Dyah.erpe@gmail.com

${ }^{2}$ Dosen AKPER Widya Husada Semarang. Email :maulidtakw@gmail.com

${ }^{3}$ Dosen AKPER Widya Husada Semarang. Email :lithafikha@gmail.com 
Kepatuhan Pengobatan pada Pada Pasien Tuberkulosis di RSUD dr. Soehadi Prijonegoro Sragen. Farmasi Sains Dan Praktis, II(1), 47.

Purnamasari. (2020). Tingkat Pengetahuan Dan Perilaku Masyarakat Kabupaten Wonosobo Tentang Covid-19. Jurnal Ilmiah Kesehatan, (Mei), 33-42. Retrieved from https://ojs.unsiq.ac.id/index.p $\mathrm{hp} / \mathrm{jik} /$ article/view/1311/783

Sari, \& Pramita, D. (2020). Hubungan antara pengetahuan masyarakat dengan kepatuhan penggunakan masker sebagai upaya pencegahan penyakit COVID-19 di Ngronggah. Jurnal Ilmiah Rekam Medis Dan Informatika Kesehatan, 10(1), 52-55. Retrieved from http://ojs.udb.ac.id/index.php /infokes/article/view/850

Sinuraya, R. (2018). Medication Adherence among Hypertensive Patients in Primary Healthcare in Bandung City. Indonesian Journal of Clinical Pharmacy, $7(2)$, 124-133. https://doi.org/10.15416/ijcp. 2018.7.2.124

Tim Kerja Kementerian Dalam Negeri. (2020). Pedoman Umum Menghadapi Pandemi Covid-19 Bagi Pemerintah Daerah: Pencegahan, Pengendalian, Diagnosis dan Manajemen.

$\begin{array}{lr}\text { Wang, D. 2020. } & \text { Clinical } \\ \text { Characteristics } & \text { of }\end{array}$
Hospitalized Patients With 2019 Novel CoronavirusInfected Pneumonia in Wuhan, China. JAMA. doi:10.1001/jama.2020.1585. https: / /www.medrxiv.org/cont ent/10.1101/2020.02.06.20020 974v1. full.pdf +html

World Health Organization. (2020). Global Surveillance for human infection with coronavirus disease (COVID-19) virus. Interim Guidance, (February), 27-29. Retrieved from https: / /www.who.int/publicati ons-detail/global-surveillancefor-human-infection-withnovel-coronavirus-(2019-ncov)

Wulandari, A., Rahman, F., Pujianti, N., Sari, A. R., Laily, N., Anggraini, L., ... Prasetio, D. B. (2020). Hubungan Karakteristik Individu dengan Pengetahuan tentang Pencegahan Coronavirus Disease 2019 pada Masyarakat di Kalimantan Selatan. Jurnal Kesehatan Masyarakat Indonesia, $15(1), \quad 42$. https://doi.org/10.26714/jkmi .15.1.2020.42-46

Yanti, B., Wahyudi, E., Wahiduddin, W., Novika, R. G. H., Arina, Y. M. D., Martani, N. S., \& Nawan, N. (2020). Community Knowledge, Attitudes, and Behavior Towards Social Distancing Policy As Prevention Transmission of Covid-19 in Indonesia. Jurnal Administrasi Kesehatan Indonesia, 8(2), 4. https://doi.org/10.20473/jaki. v8i2.2020.4-14

Dyah Restuning Prihati ${ }^{1}$, Maulidta K. W $^{2}$, Endang Supriyanti ${ }^{3}$

${ }^{1}$ Dosen AKPER Widya Husada Semarang. Email : Dyah.erpe@gmail.com

${ }^{2}$ Dosen AKPER Widya Husada Semarang. Email :maulidtakw@gmail.com

${ }^{3}$ Dosen AKPER Widya Husada Semarang. Email :lithafikha@gmail.com 